\title{
System supervision tasks for practicing psychologists at the initial stage
}

\author{
of professional activity.
}

\author{
Larysa Spitsyna
}

Phd, Associate Professor of Department of Psychology, Zaporizhzhia National

University, Zaporizhzhia, Ukraine

Introduction: Current trends in the development of a specialist in the field of psychology reflect the growing requirements for specialists in psychological care, and accelerated the awareness of the need to be accompanied by appropriate supervision.

Purpose: studying the opportunities and tasks of system supervision for practicing psychologists in the initial stage of professional activity.

Design/Methodology/Approach: The main part of our supervisory practice is an integrative approach implemented in the practice of intersubject interaction between the supervisor and supervisor (individuals, groups, teams, organizations).

Results. In our research, we proceed from the assumption that supervision is a form of professional counseling aimed at improving the quality of communications and cooperation in the professional context, a form of professional support in the field of helping occupations, in business, in psychological and psychotherapeutic practice, etc.

In the European model of supervision, carried out on the basis of the professional standards of the Association of national Organisation for Supervision in Europe (ANSE), in the process of group work supervisor with supervisor (group, organization) creates conditions for:

- Improvement of professional activity, first of all, due to improvement of interpersonal communication and interaction in groups;

- Solving problem, conflict situations depending on the current needs of the organization; Search for the best solution for the organization at the moment;

- Prevention of emotional burnout of employees of the organization;

- Creation of conditions for constructive communication, which involves working out and solving problems of members of the supervisory group, search and awareness of resources;

- Implementation of emotional support, achievement of understanding, allowing the client to realize the possibilities of self-help, creation of conditions for making an informed, well -balanced decision;

- Development of professional and socio-psychological competencies of employees of organizations.

Limitations and strengths of the study: Our model of supervision allows us to "include" the multi-level attention of the supervisor and, if necessary, to switch it to different aspects of his interaction with the supervisor, the content of his problem, the process and context of their interaction, the reflection of the case, which is very relevant at the initial stage of psychological practice.

Practical/Social value: This approach allows to improve the quality of professional activity, above all, by improving interpersonal communication and group interaction; 
Originality/Conclusions: We identified opportunities to use supervisory engagement resources to address a variety of professional challenges related to the professional development of a practicing psychologist.

Keywords: supervision, psychosocial support, practicing psychologist, professional experience, helping professions, professional activity.

\section{References:}

Howkins P., Shohet R. (2002) Supervision. Individual, group and organizational approaches. Ховкинс П., Шохет P. Spb (2002) Супервизия. Индивидуальный, групповой и организационный подходы. Спб.: Речь

Wiliyams Е. (2001) Уильямс Э. You are a supervisor. Six-focus model, roles and techniques in supervision. М. (2001) Вы - супервизор. Шестифокусная модель, роли и техники в супервизии. М.: Независимая фирма «Класс».

Carey, T. A., Mullan, R. J. (2004) What is Socratic questioning? Psychotherapy: Theory, Research, Practice, Training, Vol 41(3), p. 217-226. 